\title{
PROCESSING ENGLISH PREFIXED VERBS
}

\author{
Nikola Tatar
}

\begin{abstract}
This paper takes for its main aim to question whether prefixed verbs (and other morphologically complex verbs) are more demanding for processing than "regular" ones through the reading experiment that was conducted among the senior students of the English Department at the Faculty of Philosophy. It was expected that the respondents would need more time for treating verbs with additional elements and mostly they did. However, while examining the results, our attention was drawn by the fact that besides semantic priming one has to take into consideration and account for the so-called structural or morphological priming. What is more, conclusions drawn from this research might be applicable to language processing in general, since it is almost widely agreed that language is processed in the same way regardless of the modality of the input signal, which may, as it is widely known, be visual or auditory. There is only one exception: written language employs the visual cortex as an input pathway, while spoken language makes use of the auditory cortex.
\end{abstract}

Acta Medica Medianae 2018;57(4):137-143.

Key words: prefixed verbs, reading, language processing, priming

Centre for Foreign Languages, Faculty of Philosophy, University of Niš, Serbia

Contact: Nikola Tatar

Jahorinska 1, 18000 Niš, Serbia

E-mail: nikolatatar@gmail.com

\section{Introduction}

In order to elucidate the experiment which was conducted and arrive at certain conclusions, it is palpably clear that prefixation and the recognition of written words will have to be dwelled upon. Since prefixation can be dealt with in brief for the purpose of this paper, it will be discussed in the introductory part, along with language processing. However, when it comes to the visual recognition of words, it will be debated in a separate section.

Therefore, if a prefix is defined as an affix that precedes its base, then prefixation can be very easily defined as the process of adding a prefix (dis + appear $=>$ disappear). The logical question that arises here is what happens when prefixes are attached to verbs in English. Unlike in Serbian, the only special phenomenon that happens in English is the creation of a new word, because all English prefixes are of derivational nature.
Our assumption in this paper would be that verbs with no additional elements will take the smallest amount of time to be recognized and that prefixed verbs would need more time because of an added element. Then we finally reach verbs which combined with prefixes give nonwords and which should, we believe, require the largest amount of time for visual recognition. By doing all this, certain conclusions concerning language processing in general will be arrived at because language is processed in the same way regardless of the modality of the input signal, which may, as it is widely known, be visual or auditory $(1,2,3)$. Accordingly, before visual word recognition is dealt with, we ought to explain what is meant by language processing.

The above-mentioned phenomenon refers to the system how human beings process writing or speech and understand it as language. It should be highlighted that it does not matter what kind of stimulus is offered (visual or auditory), language processing will operate in an utterly similar way, with only one exception: spoken language employs the auditory cortex as an input pathway, while written language makes use of the primary visual cortex. Contemporary theories support the idea that this process is done completely by and inside the brain. The auditive organ receives acoustic stimuli and they are converted to bioelectric signals on the organ of Corti. These electric impulses are then transported through scarpa's ganglion (vestibulocochlear nerve) to the primary auditory cortex, on both hemispheres. What is important here is that each hemisphere treats it in a different way. While the right side is in charge of taking over prosodic characteristics and 
melodic information, the left side recognizes distinctive parts such as phonemes. After this, the signal is transported to Wernicke's area on the left hemisphere where the already noted analysis takes part (the information which was being processed on the right hemisphere is able to cross through inter-hemispheric axons). The signal then travels from this area to Broca's area through what is referred to as the arcuate fasciculus. Broca's area is responsible for interpreting the information provided by Wernicke's area (using the pars triangularis) and it also transmits the information to the closely located motorrelated areas of the brain for production of speech (relying on the pars opercularis) (4).

\section{Written word recognition}

Scientists have always wanted to know what processes the brain engages in when making the way from a visual input of crisscrossed lines and curves to making contact with meaning. This question has brought about a considerable amount of research, and it has generated findings that inform us of not only psycholinguistics but also of domains as diverse as computational modelling, automatic and attentional processes, pattern recognition, and the neural substrates of language processing. (5) Research at the word level is particularly manageable and illuminating as words are well-defined units which can be investigated and processed at different levels (i.e., spelling, sound, grammar, meaning) (6).

Researchers have developed many procedures in order to study the processes involved in word recognition. For instance, with the procedure of perceptual identification, words are visually degraded by masking or brief presentations, and subjects are asked to identify them, and in this particular case identification accuracy is the dependent measure. There are also eye-tracking studies, in which subjects' eye movements (e.g., fixation, location, and duration) are tracked as they read text. With semantic categorization tasks, researchers ask examinees to classify words (e.g., Is dog an animal?), and here response latency and accuracy are the dependent measures. In neuroimaging studies, conclusions about the processes included in word recognition are created from on-line measures of the time course and location of neural activity via event related potentials, positron emission tomography*, or functional magnetic resonance imaging. Individuals with isolated disruptions in reading (specific subtypes of dyslexia) are also studied by researchers so that they could better understand normal reading (5).

\footnotetext{
* Positron Emission Tomography (PET) represents a technique for imaging internal body tissues in nuclear medicine. PET requires a cyclotron as an on-site source of short-lived positron-emitting isotopes. The isotopes are injected into the patient along with a glucose-related compound, and the positrons collide with electrons in body tissues to produce photons. The photons are tracked by a tomographic scintillation counter, and the information is processed by a computer to provide both images and data on blood flow and metabolic processes within the tissues that are observed. What everybody agrees on is that PET scans are particularly convenient and practical for diagnosing brain tumors and the consequences which strokes may have on the brain, along with various mental illnesses. PET scans also found their use in brain research and the mapping of brain functions (8).
}

138
Although benefits could be found in each of these approaches, there are also some costs (7). Therefore, two relatively simple tasks (lexical decision and naming) are most heavily relied on when researchers want to investigate isolated word recognition. With the task called speeded lexical decision, examinees are presented with either a real word or a nonword (e.g., flirp), and their task is to make the word/nonword discrimination as quickly and as accurately as possible. There is also speeded naming, in which words (and very often nonwords) are visually presented to interviewees and they are asked to utter the words aloud as quickly and accurately as they can. In both tasks, scientists' primary interest is in how quickly people can name words or make lexical decisions in different experimental conditions. There is always the assumption that naming and lexical decision latencies reflect processes included in accessing lexical representations (9).

It would be useful to point out here that many models have been put forward which would explain how word recognition takes place. The logogen model was one of the earliest models that was proposed, and it postulates that there is a word detector (logogen) for every word in the reader's lexicon. Every logogen has a certain resting level of activation, and when a word is presented, the logogen for that particular word gathers evidence till a certain threshold is reached. It should be underlined that word recognition occurs at this juncture (10).

McClelland and Rumelhart used the logogen framework as a basis to develop a very influential model of word recognition. They named it the interactive activation model (IAM) and it includes three processing levels (visual, letter, word), while a node represents respective units within each level. When there is a visual input, it first stimulates feature-level nodes, which then activate letter level nodes, and finally word-level nodes (which correspond to logogens) are activated. Eventually, every node reflects the activation spreading across the units, and the effect of a variable can be tested by studying the value of a node after the specified amount of time has elapsed. The afore-mentioned model explains many findings in the literature. A good example would be the finding that people can identify frequently encountered words (world) more quickly than rarely encountered ones (such as glitch). This is the effect of word frequency, and it suggests the fact that highfrequency word nodes have lower recognition thresholds than low-frequency ones. So, the former need less evidence to be recognized, while the latter require more evidence (11).

There is one important aspect of the IAM that needs to be mentioned here and that is its parallel and cascadic nature. In particular, in the course of word recognition, we do not simply recognize a word independently of other words stored in our lexicon. Actually, it is many words that receive activation, and the model finally arrives at the appropriate representation across time, through a set of facilitatory and inhibitory pathways. One finding is interesting enough because it is in accordance with the activa- 
tion of multiple words en route to recognition. It is called the orthographic neighbourhood effect. An orthographic neighbour stands for a word that can be produced by another word if only a single letter is changed (12). The following example is suitable to illustrate this point. The word can has the neighbours cap, cat, pan, man, among many others. The orthographic neighbourhood effect implies that words with more orthographic neighbours yield faster response latencies than words with few orthographic neighbours. This effect is larger for low-frequency words. Based on this, it does not come as a surprise that multiple lexical units seem to be activated when one word is presented. Of course, just the opposite pattern might have been expected, because of inhibition of competitors, a prediction from the original IAM. Even though contemporary embellishments of components of the interactive activation model can accommodate orthographic neighbourhood effects $(5,13)$, this is an important area that is still being actively researched and therefore we cannot include it in our experiment.

\section{The experiment}

This portion will begin with the description of the experiment, and the presentation of the results in two ways will follow. The results will be represented by using numbers (Table 3 ) and then the results will be discussed and certain inferences will be drawn.

When it comes to our experiment, which is of behavioural character, since a stimulus (a word snake) is offered to our participants and their latencies, or reaction times, are recorded, it should also be said that it represents a modification of self-paced reading. The test used for the experiment consists of six word snakes. Each word snake is comprised of five content words with no spaces between them, as it can be illustrated in Table 1. Every snake contains two nouns, two verbs and one adjective or adverb. It is of vital importance for this experiment to mention here which principles guided our choice of words.

Table 1. Problems (word snakes) presented to examinees

\begin{tabular}{||c||l||}
\hline 1$)$ & yawnopportunitybulletcompeteawkwardly \\
\hline 2$)$ & alternativebouncestifflyluggageinvestigate \\
\hline 3$)$ & deliberatelyoverbuildartificiallypredominatepension \\
\hline 4$)$ & genuinelyrearrangelaughterjewellerydisregard \\
\hline 5$)$ & pronunciationpreimposerhythmquotealphabetically \\
\hline 6$)$ & environmentallyelevatorurgeunbelievecircumstance \\
\hline
\end{tabular}

Table 2. Answers to word snakes

\begin{tabular}{|c|c|}
\hline & Answers: \\
\hline 1) & yawn । opportunity । bullet । compete । awkwardly \\
\hline 2) & alternative । bounce । stiffly । luggage । investigate \\
\hline 3) & deliberately I overbuild । artificially । predominate । pension \\
\hline 4) & genuinely I rearrange । laughter । jewellery । disregard \\
\hline 5) & pronunciation । preimpose । rhythm । quote । alphabetically \\
\hline 6) & environmentally I elevator I urge । unbelieve I circumstance \\
\hline
\end{tabular}

English examples were chosen from the list of three thousand words which are offered by Oxford. The keywords of the Oxford 3000 have been carefully selected by a group of language experts and experienced teachers as the words which should receive priority in vocabulary study because of their importance and usefulness. All the words that make up the Oxford 3000 can be found at the appropriate website (14).
This group of words was chosen because it was thought that every candidate focused on them during his or her studies. As for examinees, there were ten of them and all of them were senior students of the English Department at the Faculty of Philosophy in Niš. Their task in this small-scale research was to make 5 meaningful units (words) by dividing each word snake with only four vertical lines. The amount of time which candidates needed to com- 
plete each word chain was measured. The answers can be found in Table 2.

Before we move on to see the solutions, we should probably point out here that examinees could not see all the word snakes they had to split. The word chains were covered with another piece of paper while the experiment was being carried out. The chains were uncovered one by one as the candidates finished dealing with the previous word chain. In no possible way could they see the word snake which they were about to cope with.

It should also be said that if an interviewee does not complete the task in 15 seconds, he or she will have to stop and proceed to the next word snake. The same rule is applied to mistakes. If an interviewee has made a mistake he or she can rectify it if he or she has got enough time, i.e. if 15 seconds have not elapsed. It can be easily noticed that none of these figures in Table 3 reaches 15.00 seconds, which means that none of the examinees erred while they were "chopping" these strings of words.

Now it seems the right time to mention that these results are going to be contrasted within the language itself. But before we start doing any of this, we should probably first explain what phenomenon each pair of these word snakes questions.

The first two English word snakes simply question how much time it takes to visually recognize and divide verbs without any affixes. As it can be seen, the target verbs are: yawn, compete, bounce and investigate. The average times which are taken from these two examples will serve as some kind of standard value which will be compared to all the other average values. This does not mean that other average values will not be compared to one another, this basically means that the first average value will merely serve as a starting point.

\begin{tabular}{||l||l||}
\hline Example 1 & yawnopportunitybulletcompeteawkwardly \\
\hline Example 2 & alternativebouncestifflyluggageinvestigate \\
\hline Example 3 & deliberatelyoverbuildartificiallypredominatepension \\
\hline Example 4 & genuinelyrearrangelaughterjewellerydisregard \\
\hline Example 5 & pronunciationpreimposerhythmquotealphabetically \\
\hline Example 6 & environmentallyelevatorurgeunbelievecircumstance \\
\hline
\end{tabular}

The third and the fourth word snake, or the second pair of examples, is used to show how many seconds our candidates needed to visibly distinguish prefixed verbs. The verbs we are focused on here are: overbuild, predominate, rearrange and disregard. The average values which are calculated based on these two clusters of words will be of vital importance because the figures stand for the main issue we are examining here.

It should be said that the last pair of English examples is very significant for this paper. By offering these two word snakes to our examinees, we hoped to find out how many seconds it took the examinees to visibly diagnose that something is wrong here, i.e. to sight that the prefixes pre- and un- do not create meaningful prefixed verbs with verbs impose and believe ( $v$. Table 3). Despite the facts that the examinees were not told anything about this and that they were expected to reach the maximum of 15 seconds here, our candidates dealt with this pair fascinatingly well. Not a single one of them made a mistake, and we will have to pay a lot of attention to examples 5 and 6 when we start giving explanations.

After a full account of the experiment has been given, and before we commence comparing calculations done based on the results of the experi- ment, attention should be called to the point that all the conclusions that will be drawn here refer only to the corpus of words that make up the word snakes.

\section{Results}

Only after we state a couple of facts about our anticipation of the results, will we start commenting the real results, which are gathered in Table 3. The table shows latency times for all word snakes, which are marked from E1 to E6, and for each candidate. After that, average values for each word snake and average values for pairs of word snakes which questioned the same phenomenon are presented.

It was expected that latency times for responses would grow with the addition of elements (prefixes) to verbs. In other words, we thought that candidates would need more time to graphically parcel out each following word snake or pair of word snakes due to its or their more complex structure. Naturally, it was believed that the largest amount of time would be required for the last two instances. Whether this was really accurate can be checked in the above-mentioned table, which will be used as a reference. 
Table 3. Experiment results

\begin{tabular}{|c|c|c|c|c|c|c|}
\hline CANDIDATES & E1 & E2 & E3 & $\mathrm{E} 4$ & E5 & E6 \\
\hline CANDIDATE 1 & 11.72 & 6.44 & 8.94 & 13.86 & 9.28 & 6.66 \\
\hline CANDIDATE 2 & 11.34 & 8.47 & 9.50 & 12.87 & 12.53 & 8.97 \\
\hline CANDIDATE 3 & 10.57 & 7.68 & 8.83 & 10.54 & 10.06 & 9.28 \\
\hline CANDIDATE 4 & 12.60 & 8.19 & 10.79 & 9.88 & 11.50 & 10.07 \\
\hline CANDIDATE 5 & 11.54 & 9.88 & 11.06 & 10.48 & 12.06 & 11.38 \\
\hline CANDIDATE 6 & 13.00 & 11.95 & 13.41 & 12.19 & 13.06 & 11.24 \\
\hline CANDIDATE 7 & 12.59 & 10.83 & 11.27 & 11.03 & 13.81 & 12.32 \\
\hline CANDIDATE 8 & 12.74 & 11.58 & 11.99 & 10.89 & 13.02 & 11.76 \\
\hline CANDIDATE 9 & 9.24 & 8.71 & 12.30 & 11.41 & 11.21 & 10.48 \\
\hline CANDIDATE 10 & 10.74 & 11.83 & 12.35 & 10.68 & 14.12 & 13.57 \\
\hline AVERAGE TIME & 11.60 & 9.55 & 11.04 & 11.38 & 12.06 & 10.57 \\
\hline $\begin{array}{c}\text { Average time for } \\
\text { two examples }\end{array}$ & \multicolumn{2}{|c|}{$\underline{10.57}$} & \multicolumn{2}{|c|}{$\underline{11.21}$} & \multicolumn{2}{|c|}{$\underline{11.31}$} \\
\hline
\end{tabular}

\section{Discussion}

If we cast a quick glance at the average times, we will easily notice that the average times for the first example in each pair are larger than the second one. The only exception is the second pair of examples, in which the average time for the first example is smaller. But, let us get back to the phenomenon that can be ascribed to the remaining two pairs. This phenomenon can be explained by "morphological" priming. By solving the first word snake in one of the two pairs, the examinees must have somehow adapted their apparatuses which are used for visual word recognition for the structure of the target words in the second word snake and found it easier. Therefore, this can be seen as some kind of positive morphological priming. But, as this kind of priming cannot be attributed to the second pair of examples because E4 is larger in value than E3, we have to introduce the concept of negative morphological priming, which characterizes the second English duo.

The average latency times for the starting two examples are 11.60 seconds for the first one and 9.55 seconds for the second one. That makes the average of 10.57 seconds for these two instances. If we compare this result to the arithmetic mean for the second pair of examples which is 11.21 , it can effortlessly be spotted that we were right: prefixed verbs necessitated students taking more time to finish the given task. Prima facie, it seems that, on average, the interviewees took additional 0.64 seconds to visually recognize prefixed verbs. However, when we compare E1 to E3 and E2 to E4, we can see that response times for E1 and E3 are almost the same and that E2 and E4 are the ones that create this difference, which can be attributed to the well-known element that is added in front of the verbs, also known as a prefix.

We have already pointed out the fact that there was no positive priming with the second pair of examples. With these two examples we can rather talk about negative priming. The difference between E3 and E4 is not as big as it may seem, it is 0.34 seconds, and some might say that this difference cannot be ascribed to negative priming due to its shortness. On the other hand, we have to take into consideration that E4 is the only second example out of all the pairs of word snakes which increased, i.e. latency times for E2 and E6 decreased in comparison to their respective counterparts, E1 and E5. Thus, it can be concluded that we can talk about negative priming with prefixed verbs. Since in our experiment we dealt with the verbs which with prefixes yield non-words (examples 5 and 6 ), we should underline that negative priming is only connected to prefixed verbs which have meaning.

When the last pair, or examples 5 and 6, is taken into consideration, it can be seen that E5 and E6 did not bring the discrepancy between our expectations and the statistic for the final pair. It was reckoned that the contestants of the research would most arduously find the solution to the last pair of examples, because the verbs in combination with prefixes yielded non-words. Since we have covered all 6 examples, it can now be said that we have two word snakes with the largest average time, they are E5 and E6. This indicates that these two examples 
along with the problem they carry are the most challenging to handle. In comparison with the first pair of examples, it can be perceived that the interviewees were in need of additional 0.34 seconds when they were solving the third pair of examples. It is obvious, but we must mention it again, students found the first two examples easy and the third pair the most difficult due to the facts that the former have "no-additional-element" verbs and the latter are combined with an additional prefix with which they created non-existing words, which must have puzzled the examinees most. The difference between the first and the last pair of is 0.74 seconds on behalf of the last pair, while the difference between E3 and E4 on the one hand and E5 and E6 on the other amounts to 0.10 seconds.

Another aspect of the last pair should be looked at and that is whether positive priming is expressed. From the very first sight, positive priming is noticeable. The first word snake in the last couple was unravelled in 12.06 seconds and the second word snake in 10.57 seconds. Positive priming here adds up to 1.49 seconds, which makes it the second largest in terms of positive priming. The first pair is typified by the largest amount of positive priming and it is 2.05 seconds. As it has already been said, only one pair of examples is characterized by negative priming and that is the second duo: interviewees finished E4 in 0.34 seconds faster than E3.

\section{Conclusion}

The main purpose of this paper was not to compare many authors' points of view on the aforementioned topics, but to create a theoretical back- ground for our research. It was reckoned that explaining the word detector model (logogen) and the interactive activation model (IAM) would be sufficient for visual recognition and language processing in general. The results which were obtained only from the examples showed that more complicated verbs were mostly recognized more slowly. However, what is mainly perceived with these instances is the socalled morphological priming. This phrase actually means that spotting the written form of a word which is characterized by a particular morphological structure (in our case, a verb is this word to which structural elements are added, primarily prefixes) would either delay or accelerate visual recognition of a next word which is morphologically the same.

After the experiment, which consisted of ten word chains containing verbs with different extra elements, has been carried out among the senior students of English, we first contrasted the results, and based on this comparison, particular conclusions can be drawn. First, English prefixed verbs are more complicated for recognition and language processing than simple verbs, which can be ascribed to the morphological complexity, i.e. additional elements. Cutler states that bases and affixes (including prefixes) are processed separately, so basically with prefixed verbs students had to deal with two units, not just one (15). Second, nonword prefixed words are even more complicated for processing and recognition, most likely due to their complexity and most of all impossibility to be combined. Finally, morphological priming, be it positive or negative, is a feature that must be taken into consideration with this kind of research.

\section{References}

1. Mildner V. The Cognitive Neuroscience of Human Communication. New York: Taylor \& Francis Group; 2007.

2. Keith R, Kiefte K Kiefte M. In: Traxler MJ, Gernsbacher AM, editors. Handbook of Psycholinguistics. USA: Academic Press; 2006. p. 153-99.

3. Kutas M, Van Petten CK, Kluender R. In: Traxler MJ, Gernsbacher AM, editors. Handbook of Psycholinguistics. USA: Academic Press; 2006. p. 659-724. [CrossRef]

4. Pinker S. The Language Instinct. New York: W. Morrow and Co; 1994. [CrossRef]

5. Brown K. Encyclopedia of Language and Linguistics. $2^{\text {nd }}$ edition. Elsevier; 2005.

6. Balota DA. Visual word recognition: the journey from features to meaning. In: Gernsbacher $M A$, editor. Handbook of psycholinguistics. San Diego: Academic Press; 1994. p. 303-48.
7. Balota DA, Cortese MJ, Sergent-Marshall SD, Spieler $\mathrm{DH}$, Yap MJ. Visual word recognition of singlesyllable words. J Exp Psychol Gen 2004; 133(2):283-316. [CrossRef] [PubMed]

8. Microsoft ${ }^{\circledR}$ Student 2009 [DVD]. Redmond, WA: Microsoft Corporation; 2008. [CrossRef] [PubMed]

9. Seidenberg MS. Lexical access: another theoretical soupstone? In: Balota DA., Flores, d'Arcais GB,Rayner $\mathrm{K}$, editors. Comprehension processes in reading. Hillsdale: Lawrence Erlbaum Associates; 1990. p. 33-71.

10. Morton J. A functional model for human memory. In: Norman DA, editor. Models of human memory. New York: Academic Press; 1970. p. 203-60. [CrossRef]

11. McClelland JL, Rumelhart DE. An interactive activation model of context effects in letter perception, part 1 : an account of basic findings. Psychological Review 1981; 88: 375-407. [CrossRef] 
12. Coltheart M, Davelaar E, Jonasson J, Besner D. Access to the internal lexicon. In: Dornic S, editor. Hillsdale: Lawrence Erlbaum Associates; 1977.

13. Grainger J, Jacobs AM. Orthographic processing in visual word recognition: a multiple read-out model. Psychological Review 1996; 103: 518-65. [CrossRef] [PubMed]
14. Available from: URL: http://www.oup.com/eltnew/catalogue/teachersites/o ald7/oxford 3000/oxford 3000 list?cc=global

15. Cutler A, Hawkins JA, Gilligan G. The suffixing preference: A processing explanation. Linguistics 1985; 23: 723-58. [CrossRef]

\title{
Originalni rad
}

\section{MENTALNA OBRADA ENGLESKIH GLAGOLA SA PREFIKSOM}

\author{
Nikola Tatar \\ Univerzitet u Nišu, Filozofski fakultet, Centar za strane jezike, Niš, Srbija \\ Kontakt: Nikola Tatar \\ Jahorinska 1, 18000 Niš, Srbija \\ E-mail: nikolatatar@gmail.com
}

Glavni cilj ovog rada je da se kroz eksperiment vizuelnog prepoznavanja, koji je sproveden među studentima završne godine Departaman za anglistiku Filozofskog fakulteta, ispita da li su glagoli sa prefiksom (kao i drugi morfološki kompleksni glagoli) teži za mentalnu obradu od onih ",običnih". Očekivalo se da će ispitanicima biti potrebno više vremena za obradu glagola sa dodatnim elementima i to je uglavnom bilo tačno. Međutim, prilikom obrade rezuItata, skrenula nam je pažnju činjenica da pored semantičkog prajminga, treba uzeti u obzir i objasniti takozvani strukturalistički ili morfološki prajming. Štaviše, zaključci doneti na osnovu ovog istraživanja mogli bi se primeniti na razmatranja o obradi jezika u opštem smislu, budući da je opšte poznato da se jezik procesuira uvek na isti način, bez obzira na modalitet inputa, koji, kako je poznato, može biti vizuelni ili auditivni. Postoji samo jedna razlika, pisani jezik angažuje vizuelni korteks kao ulazni put, dok govorni jezik angažuje auditivni korteks.

Acta Medica Medianae 2018;57(4):137-143.

Ključne reči: glagoli sa prefiksom, čitanje, mentalna obrada jezika, prajming 